\title{
Variation and genetic analysis of fatty acid composition in flax (Linum usitatissimum L.)
}

\author{
Magdalena Walkowiak (1D) Stanislaw Spasibionek • Krystyna Krótka
}

Received: 24 November 2020/ Accepted: 23 October 2021/Published online: 7 December 2021

(C) The Author(s) 2021

\begin{abstract}
Flax (Linum usitatissimum L.) is an important source of oil rich in omega-3 fatty acids (especially $\alpha$-linolenic acid accounting for $>50 \%$ ), which is proven to have health benefits and utilized as an industrial raw material. $\alpha$-Linolenic acid is a polyunsaturated fatty acid that readily undergoes oxidative transformation. Autoxidation of $\alpha$-linolenic acid is the principal process contributing to the development of off-flavors, loss of color, and alteration in the nutritional value of linseed oil. However, there is huge a demand on the market for oils having different compositions of fatty acids, including the linseed oil characterized by improved stability. For this purpose, a complete diallel cross was performed in this study using six flax genotypes varying in the fatty acid content to estimate the genetic parameters. The analysis of variances carried out for the studied traits (content of oleic, linoleic and $\alpha$-linolenic acid) indicated large differences among the genotypes. Variances due to GCA were much higher in magnitude than those related to SCA for the content of linoleic and $\alpha$-linolenic acid, which indicated the superiority of additive gene effects in determining the inheritance of these traits. The nonadditive gene action played an important role for oleic acid content, since the
\end{abstract}

M. Walkowiak $(\bowtie) \cdot$ S. Spasibionek · K. Krótka Department of Genetics and Breeding of Oilseed Crops, Plant Breeding and Acclimatization Institute-National Research Institute (PBAI-NRI), Poznan, Poland e-mail: magda@nico.ihar.poznan.pl magnitude of SCA effect was almost two times higher than GCA effect. The parental lines of linola (Linola KLA and Linola KLB) exhibited the highest concentration of favorable alleles for the two traits (high content of linoleic acid and low content of $\alpha$-linolenic acid) and were thus found suitable for a continuous improvement program. On the basis of the SCA effect, five cross combinations, were found to be promising F1 hybrids for use as a source population for further selection, in order to achieve fatty acid changes in linseed. These combinations allow selecting varieties with $1: 1$ and 2:1 ratio of omega-6:omega-3 fatty acids for producing oil with an extended shelf life for food products.

Keywords Linseed - Inheritance - GCA - SCA . Oleic acid $\cdot$ Linoleic acid $\cdot \alpha$-linolenic acid

\section{Introduction}

At present, the international market of edible oilseeds is dominated by a few crop species such as soybean, oilseed rape, and sunflower. However, there is a growing demand for high-quality seed oils. Thus, there is a need to not only increase the production of major oil crops but also diversify the sources by improving and enhancing the production of minor oil crops, such as linseed (Linum usitatissimum L.). 
Linseed is one of the oldest crops grown for its seed and fiber. It was cultivated in over $2,778,000$ ha with a yield of 2,794,000 tons in the year 2017. The Russian Federation is the world's largest producer of linseed (610,118 tons), followed by Canada (507,606 tons), China (362,034 tons), India (184,000 tons), and the United States of America (97,590 tons) (FAOSTAT, 2018).

There is an increasing interest in flax cultivation due to the high nutritional value of flaxseeds as roughage and raw material for the extraction of oil which has beneficial effects on the health of humans and animals (Kumar et al. 2018). Depending on the species and variety, the composition of flaxseeds varies and they are rich in fat $(30-45 \%)$, proteins $(20-31 \%)$, and dietary fiber $(20-46 \%)$, which is responsible for their high energy value of about $5100 \mathrm{kcal} \mathrm{kg}^{-1}$ (Coskuner and Karababa 2007; Mueller et al. 2010).

The value of edible oils is determined by their fatty acid composition. Among the edible oils, flaxseed oil is the richest source of $\alpha$-linolenic acid (C18:3, omega-3), which accounts for $57 \%$, and hence has high health-promoting properties (Bickert et al. 1994; Morris 2007; Heller et al. 2010). However, an important factor limiting of the large-scale commercialization of linseed oil is its low durability.

The share of unsaturated fatty acids in linseed oil mainly includes omega-9 (oleic acid), omega-6 (linoleic acid), and omega-3 ( $\alpha$-linolenic acid) fatty acids, which are highly susceptible to oxidation (Galano et al. 2015). Generally, the rate of oxidation depends on the degree of unsaturation and increases with an increase in the amount of fatty acids with double bonds. Due to the high content of unsaturated fatty acids (especially $\alpha$-linolenic acid), linseed oil is sensitive to light and temperature and can thus undergo a rapid oxidative transformation from cis to trans form (Drozdowski 2007).

Oxidative changes can cause rancidity, including the development of off-flavors, loss of color, and alteration in nutrient value, and may lead to the production of toxic compounds, which can be detrimental to the health of consumers (Choe and Min 2009; Ahmed et al. 2016; Hall et al. 2016). In particular, lipid oxidation products have mutagenic, carcinogenic and cytotoxic properties and are considered to be risk factors for human health (Keller et al. 2015).
To counteract this undesirable effect, research is being carried out at the PBAI-NRI Department of Genetics and Breeding of Oilseed Crops, Poznan, toward obtaining high-fat forms of flax with a balanced proportion of linoleic to $\alpha$-linolenic fatty acids, which may improve the durability of oil while maintaining its high nutritional value.

The selection of appropriate components for crossing is the first and foremost step in the creation of new varieties with desired traits. For breeding new varieties, it is necessary to know how the studied traits are inherited. This will enable the breeders to choose the most efficient selection strategy and the most appropriate breeding method (Mather and Jinks 1982). Diallel crosses can provide information about the genetic control of the evaluated traits, which helps in creating and selecting segregating populations (Baker 1978). In addition, these crosses allow understanding the behavior of the parents, called general combining ability (GCA), besides their hybrid combinations, called specific combining ability (SCA). GCA indicates the average performance of a parental line in hybrid combinations and reflects the additive gene action and frequency of favorable alleles. On the other hand, SCA is used to designate the cases in which certain combinations do relatively better or worse than would be expected on the basis of GCA of the lines involved, and thus reflects nonadditive gene action (Falconer 1975).

The present study aimed to estimate the genetic parameters and the mode of inheritance for the content of polyunsaturated fatty acids in flax in a set of complete diallel crosses, and to identify superior parents for producing favorable progeniesin the oil flax breeding program.

\section{Materials and methods}

Plant materials

Six parents were crossed in a complete diallel mating scheme at PBAI-NRI (Poznan) in the Spring of 2013. The cultivars Szafir, Oliwin, Eskalina, Modran, Linola KLA, and Linola KLB were used as parents. Their characteristics based on their classification and origin are presented in Table 1 .

The division of objects into groups, performed by the Ward's method on the basis of the Mahalanobis 
Table 1 The origin of flax genotypes used as parents for producing diallel crosses

\begin{tabular}{lllll}
\hline Parent & Name & Type & Seeds colour & Origin \\
\hline P1 & Szafir & Oil & Brown & Poland \\
P2 & Oliwin & Oil & Yellow & Poland \\
P3 & Linola KLA & Oil & Yellow & Canada \\
P4 & Linola KLB & Oil & Yellow & Canada \\
P5 & Escalina & Fiber & Brown & Netherlands \\
P6 & Modran & Fiber & Brown & Poland \\
\hline
\end{tabular}

distance matrix between objects. The dendrogram shows the grouping of six parental forms based on the fatty acids content. It can be seen that there are three groups (clusters) of genotypes (Fig. 1). The two genotypes of linseed Linola KLA and Linola KLB with a high content of linoleic acid (about 70\%) and an extremely low content of $\alpha$-linolenic acid (about $2.0 \%$ ) are most similar, as the height of the link that joins them together is the smallest. The next two most similar objects are varieties of linseed Szafir and
Oliwin with a very high content of $\alpha$-linolenic acid (above 58\%) and then two varieties of fiber flax Eskalina and Modran with a medium content of $\alpha$ linolenic acid (up to $51 \%$ ).

Experiment

The 30 hybrids of $\mathrm{F} 1$ generation obtained from crossing and six parental lines were grown in a field trial at PBAI-NRI (Poznan; 52 $24^{\prime} 30^{\prime \prime} \mathrm{N} 16^{\circ} 56^{\prime} 03^{\prime \prime} \mathrm{E}$ ) during two growing seasons, 2014 and 2016. The experiments were carried out in a randomized complete block design with four replications. In the first year, sowing was performed on April 2, 2014, and in the second year, on April 5, 2016. Each of the parental lines and crosses was sown in two-row plots of 3-m length, maintaining a row-to-row spacing of $20 \mathrm{~cm}$. In each row, the plant-to-plant distance was maintained at $10 \mathrm{~cm}$ by thinning. Uniform standard agronomic practices were applied to the whole experiment from sowing till crop harvest (Wielebski et al. 2016), and the plants were appropriately irrigated. At harvest, individual plants were taken at random from each row

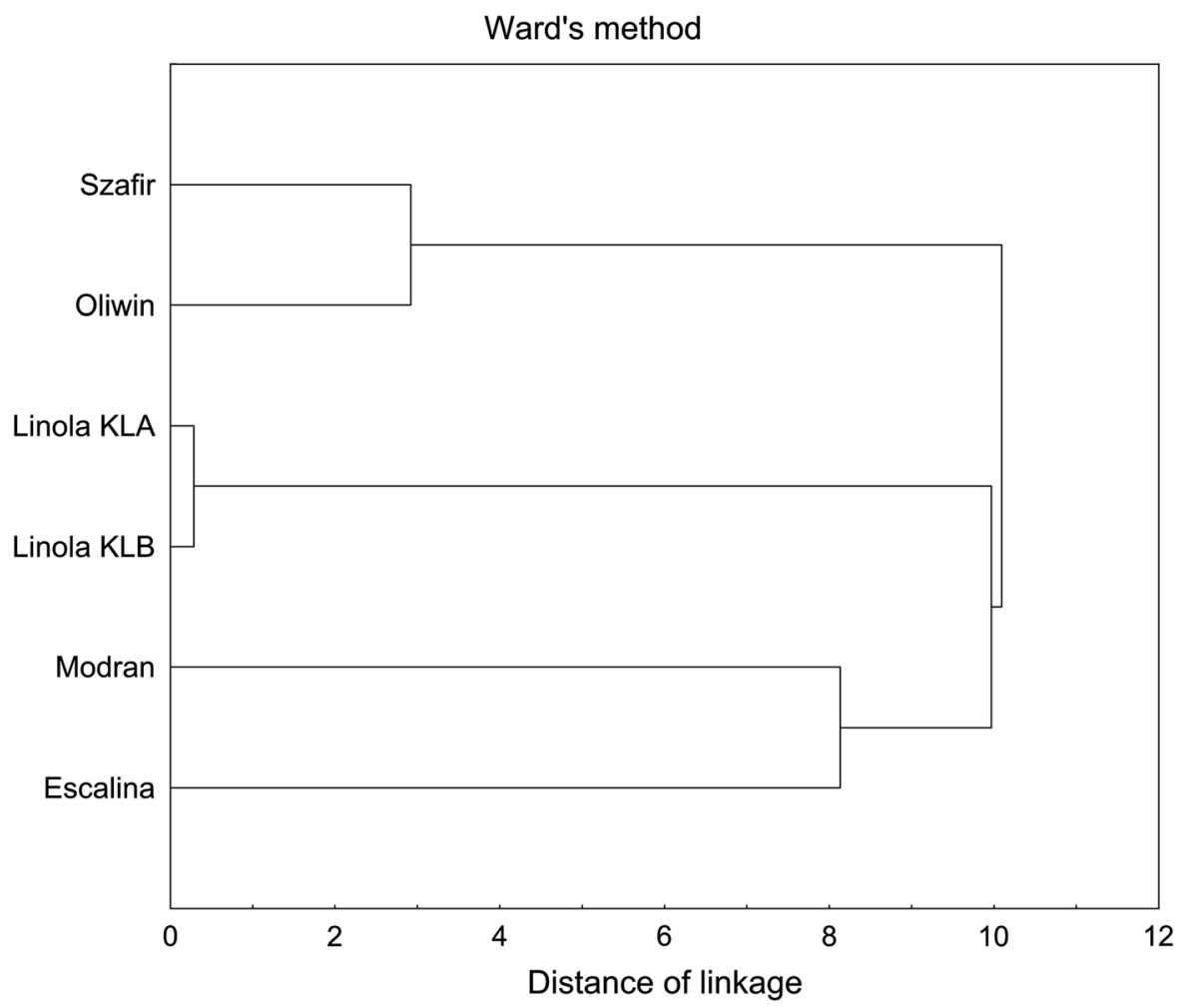

Fig. 1 Division of parental forms in groups based on the of fatty acids content 
plot; 8 to 12 plants from each parent and F1 hybrids for the analysis of fatty acid composition.

Chemical analysis

Biochemical analysis of the fatty acid composition in seed oil was performed using a Hewlett Packard Agilent Technologies 6890 N Network GC System.

Statistical analysis

The means were calculated for 8-12 plants from each parent and F1 hybrids during for years 2014, 2016 and together.

The analysis of variance for GCA and SCA and the effects of reverse crosses in a series of experiments with genotypes obtained from a complete diallel crossing system (Griffing method I), the linear variance analysis model was assumed (Griffing 1956). The data from experiments were processed using the computer program SERGEN (Caliński et al. 1998).

All genetic parameters and heritability were determined for the F1 generation using DGH2 software (Kala et al.1996), developed for the needs of genetic and breeding experiments, including those carried out on genotypes obtained from diallel crossing. The DGH2 program is based on the mathematical methods presented in Mather (1949), Hayman (1954), Mother and Jinks (1982).

For conducting genetic analysis as described by Mather (1949), it was assumed that all the following conditions were met: disomic inheritance, normal variability distribution, no epistasis, and no differences in reverse crossings.

From the distribution of mean squares obtained from variance analysis of the diallel table on the expected values, the genetic parameters $\mathrm{D}, \mathrm{H}_{1}, \mathrm{H}_{2}, \mathrm{~F}$, and $\mathrm{h}^{2}$ were estimated according to Mather (1949).

- $\mathrm{D}$ is defined as the component of variation due to the additive effects of genes.

- $\mathrm{H}_{1}$ is defined as the component of variation due to the dominance effects of genes.

- $\mathrm{H}_{2}$ is defined as the component of variation arising from $h$ increments of all segregating genes, or the dominance component indicating the asymmetry of positive and negative effects of genes.

- $\mathrm{F}$ is defined as an indicator of relative frequencies of dominant and recessive alleles.
- $\mathrm{h}^{2}$ is defined as the estimate of the overall mean dominance effect of heterozygous loci.

These parameters were used to calculate the genetic coefficients to determine the predominant or recessive action of genes (Hayman 1954).

Furthermore, the following genetic parameters were estimated according to Mother and Jinks (1982).

- $\left(H_{1} / D\right)^{1 / 2}$ is the mean degree of dominance in one locus. $\mathrm{H}_{1}=\mathrm{D}$ indicates full dominance, $\mathrm{H}_{1} \gg \mathrm{D}$ indicates overdominance, and $\mathrm{H}_{1} \ll \mathrm{D}$ indicates incomplete dominance. No dominance occurs when $\mathrm{H}_{1} \leq 0$.

- $\mathrm{h}^{2} / \mathrm{H}_{2}$ is the minimum number of gene groups controlling the given trait and indicating dominance.

- $\mathrm{H}_{2} / 4 \mathrm{H}_{1}$ is the relative distribution of dominant alleles. When the frequency of dominant genes is equal to that of recessive genes, this coefficient equals 0.25 .

- $\left[\left(\mathrm{DH}_{1}\right)^{1 / 2}+\mathrm{F}\right] /\left[\left(4 \mathrm{DH}_{1}\right)^{1 / 2}-\mathrm{F}\right]$ is the mean dominant-to-recessive gene ratio for $\underline{\mathrm{n}}$ of inbred lines.

- $\left(h^{2} \mathrm{BS}\right)$ indicates heritability in the broad sense.

- $\left(\mathrm{h}^{2} \mathrm{NS}\right)$ indicates heritability in the narrow sense.

\section{Results and discussion}

One of the more difficult stages in plant culture is the selection of components for crosses (Sughroue 1995). Flax does not occur in the natural environment with variable amounts of fatty acids, and thus not could be used as breeding material to increase the genetic variability of these traits. Mutagenesis has played a significant role in obtaining flax genotypes with altered proportions of polyunsaturated fatty acids. For instance, Green and Marshall (1984) treated flax cv. Glenelg with ethyl methanesulfonate (EMS) and obtained two mutant lines (M1589 and M1722) with considerably reduced content of $\alpha$-linolenic acid (29\%). A further reduction in the content of this fatty acid, to $<2 \%$, was achieved by the recombination of these lines (Green 1986), which resulted in the creation of several types of Linola TM cultivars with a considerably lower $\alpha$-linolenic acid content of 2-3\% (Dribnenki and Green 1995; Dribnenki et al. 1999, 2003, 2004, 2005, 2007). 
To assess the inheritance of fatty acids, namely oleic, linoleic, and $\alpha$-linolenic acid, genotypes with considerably varying proportions of fatty acids were selected: two parental lines of linseed with a very high content of $\alpha$-linolenic acid (above 58\%) (Szafir, Oliwin), two parental lines of linseed with a high content of linoleic acid (above 70\%) and an extremely low content of $\alpha$-linolenic acid (about 2.0\%) (varieties selected from mutants: Linola KLA, Linola KLB), and two parental lines of fiber flax with a medium content of $\alpha$-linolenic acid (about 50\%) (Eskalina, Modran) (Table 3).This approach is promising, as reported by Christie and Shattuck (1992), to obtain potential hybrid combinations having desired alleles. In the present investigation, the combining ability estimates for three 18-carbon fatty acids-oleic, linoleic, and $\alpha$ linolenic-were analyzed in $30 \mathrm{~F} 1$ progenies derived from six parents in a complete diallel mating design.

\section{Diallel analysis of variance}

The preliminary analysis of variance was performed using the method of Griffing (1956) on the data of three 18-carbon fatty acids: oleic, linoleic, and $\alpha$ linolenic estimate the amount of variability for these characteristics among parents, F1 hybrids and F1 reciprocals (Table 2). These findings provided evidence for the presence of high considerable amount genetic variability among the genotypes $(G)$ (parental of linseed and fiber flax and their respective hybrids F1), which may facilitate genetic improvement using such genetic pools of flax. Results showed that significant differences were found among the years
(Y) for all the studied traits. The significant mean squares the interaction of ( $\mathrm{G} \times \mathrm{Y}$ ) for oleic, linoleic, and $\alpha$-linolenic acids content indicated that the magnitude of the traits in different genotypes varied over the years, indicating that on these fatty acids was affected by the environmental conditions. The estimates of variance for GCA, SCA and reciprocal effects $(\mathrm{R})$ were found to be highly significant for all the studied fatty acids. In cases where GCA is significant, it can be inferred that at least one of the parents differs from the others regarding the concentration of favorable alleles (Pimentel et al. 2013). Hence, the significance of GCA effects is indicative of the existence of parents who contribute to a greater number of favorable alleles for these traits to be transmitted to offspring (Hallauer et al. 2010]. Significant SCA effects reveal that there are deviations in the behavior of the hybrids compared to what was expected based on the parent's GCA (Teodoro et al. 2019). The GCA is attributed to genes with additive effects, whereas SCA is related to nonadditive gene effects (Sughroue 1995). Therefore, the presence of significant GCA and SCA effects show the importance of both additive and nonadditive genetic components controlling the studied traits. Based on the diallel analysis, it is possible to evaluate the relative importance of additive gene effects (expressed by GCA effects), as well as the effects due to dominance (associated with SCA). This information is useful in establishing the best breeding strategy (Baker 1978). In this study the GCA mean squares was higher than the SCA mean squares for linoleic and $\alpha$-linolenic acids content reveal the predominance of additive

Table 2 Analysis of variance for the fatty acid content of hybrids in F1generation - diallel model I according to Griffing

\begin{tabular}{llcrr}
\hline Source of variation & Degrees of freedom & $\begin{array}{l}\text { Oleic acid C18:1 } \\
\text { Mean square }\end{array}$ & Linoleic acid C18:2 & $\alpha-$ Linolenic acid C18:3 \\
\hline Genotypes (G) & 35 & $176.07^{* *}$ & $5310.95^{* *}$ & $50.96 .92^{* * *}$ \\
Years (Y) & 1 & $675.35^{* *}$ & $23.69^{*}$ & $532.63^{* *}$ \\
G x Y & 35 & $14.58^{* *}$ & $12.20^{* *}$ & $18.42^{* *}$ \\
Reciprocal (R) & 15 & $179.61^{* *}$ & $896.12^{* *}$ & $743.02^{* *}$ \\
GCA & 5 & $102.86^{*}$ & $29,870.00^{* *}$ & $29,430.00^{* *}$ \\
SCA & 15 & $184.01^{* *}$ & $1197.18^{* *}$ & $727.55^{* *}$ \\
Error & 731 & 1.66 & 6.29 & 6.03 \\
GCA/SCA & & 0.56 & 24.95 & 40.45
\end{tabular}

Significant $F$ statistic: *at a level of $\alpha \leq 0.05$; **at a level of $\alpha \leq 0.01$ 
effects on the control of this traits. The nonadditive gene action played an important role for oleic acid content, since the magnitude of SCA effect was almost two times higher than GCA effect. The calculated GCA/SCA ratio was more than unity for linoleic acid (24.95) and $\alpha$-linolenic acid (40.45), indicating that these traits are predominantly controlled by additive gene action. On the other hand, for oleic acid, the GCA/SCA ratio was less than one (0.56), indicating that this trait is mainly controlled by nonadditive action of genes. As stated in other studies (Patil and Chopde 1981; Krzymański et al. 1993; Machikowa et al. 2011), the large difference between GCA and SCA allows achieving improvements in the given trait by selecting parents that transmit the desired traits to their progeny characterized by additive gene effect. Studies involving genetic analysis of the content of fatty acids in seed oil and research on yield-forming traits (Patil et al. 1981; Mercel et al. 1990; Góral et al. 2006, 2008) revealed that highly significant difference between GCA and SCA was already noticeable in F1 generation, which points to the dominance of additive variability over nonadditive variability.

Combining ability effects of parents and F1 populations

The combining ability analysis was performed to select better parents and crosses for their further use in the breeding program. The preliminary assessment results showing changes in the fatty acid composition of the seed oil obtained from F1 hybrids are presented in Table 3. This is also confirmed by the different Standard Deviation (SD). Significant variability was observed in the content of oleic, linoleic, and $\alpha$ linolenic acid. Four groups (a, b, c, and d) were distinguished within the 30 tested $\mathrm{F} 1$ hybrids differing in the (C18:2, omega-6)/(C18:3, omega-3) acid ratio: group a comprised 16 hybrids with omega-6:omega-3 acid ratio (0.2-0.6): 1 similar to traditional flax cultivars (Szafir, Oliwin, Eskalina, and Modran); group b comprised two hybrids with omega-6:omega-3 acid ratio (25.0-34.0):1 similar to linola-type cultivars (Linola KLA and Linola KLB); and two groups with the desired (omega-6:omega-3) acid ratio: group c with 10 hybrids having a ratio of (0.7-1.2):1 and group $\mathrm{d}$ with two hybrids having a ratio of (1.3-2.0):1 (Table 3).
GCA effect

The calculated effects of GCA for parent lines pointed to significant as well as varied effects on the progeny (Table 4). According to Pimentel et al. (2013) and Teodoro et al. (2019), the significance of GCA effects indicates the existence of parents who contribute a greater number of favorable alleles for these traits to be transmitted to progeny.

A particular emphasis should be placed on two parent linola lines (Linola KLA and Linola KLB), with the significantly highest positive GCA value for linoleic acid and significantly highest negative GCA value for $\alpha$-linolenic acid in both seasons (2014, 2016), which respectively increased the content of linoleic acid and reduced that of $\alpha$-linolenic acid in the hybrid seeds. This clearly shows that these parents are good general combiners for the two traits (high content of linoleic and low content of $\alpha$-linolenic acid) suggesting the presence of additive gene action and shall be included in the breeding program for accumulating favorable alleles in a single genetic background. Therefore, these parents can be used in a crossing program to obtain superior recombinants for the examined traits.

\section{SCA effect}

Assessment of the SCA effects of F1 parent forms revealed numerous crossing combinations with significant positive as well as negative SCA effects for the tested fatty acids (Table 5).The favorable or positive effects for the trait of increased linoleic acid content and negative effects for the trait of reduced $\alpha$ linolenic acid content (desirable due to the slower oil oxidation process) were recorded for five crossing combinations $\quad(\mathrm{P} 3 \times \mathrm{P} 1, \quad \mathrm{P} 3 \times \mathrm{P} 4, \quad \mathrm{P} 3 \times \mathrm{P} 5$, $\mathrm{P} 3 \times \mathrm{P} 6, \mathrm{P} 4 \times \mathrm{P} 2)$ in both seasons $(2014,2016)$. Therefore, these crosses could be regarded as promising combinations to be utilized either as F1 hybrids or as a source population for further selection in linseed.

These combinations allow selecting types with 1:1 and 2:1 ratio of omega-6:omega-3 acids, for producing oil with increased shelf-life for human consumption (Green et al. 2008; Ahmed et al. 2016). 
Table 3 Mean of parents and their F1 hybrids for measured characteristics of linseed

\begin{tabular}{|c|c|c|c|c|c|c|c|}
\hline \multirow[t]{2}{*}{ Genotypes } & \multicolumn{2}{|c|}{$\begin{array}{l}\text { Oleic acid C18:1 } \\
\text { (omega 9) }\end{array}$} & \multicolumn{2}{|c|}{$\begin{array}{l}\text { Linoleic acid C18:2 } \\
\text { (omega-6) }\end{array}$} & \multicolumn{2}{|c|}{$\begin{array}{l}\alpha-\text { Linolenic acid } \\
\text { C18:3(omega-3) }\end{array}$} & \multirow[t]{2}{*}{ Ratio (omega-6: omega-3) Groups } \\
\hline & Mean & SD & Mean & SD & Mean & SD & \\
\hline Szafir (P1) & 19.23 & 1.03 & 11.88 & 0.51 & 59.27 & 0.93 & $0.2: 1 \mathrm{a}$ \\
\hline Oliwin (P2) & 17.80 & 1.21 & 15.58 & 0.58 & 58.03 & 1.08 & $0.3: 1 \mathrm{a}$ \\
\hline Linola KLA (P3) & 16.97 & 0.79 & 71.27 & 0.81 & 2.14 & 0.27 & $33.4: 1 \mathrm{~b}$ \\
\hline Linola KLB (P4) & 17.55 & 0.77 & 70.18 & 0.91 & 2.08 & 0.52 & $33.7: 1 \mathrm{~b}$ \\
\hline Escalina (P5) & 23.13 & 0.90 & 15.69 & 0.97 & 52.31 & 0.96 & $0.3: 1 \mathrm{a}$ \\
\hline Modran (P6) & 21.03 & 1.03 & 17.99 & 0.91 & 50.35 & 1.23 & $0.4: 1 \mathrm{a}$ \\
\hline P1 x P2 & 22.40 & 1.24 & 13.70 & 1.79 & 54.91 & 1.90 & $0.2: 1 \mathrm{a}$ \\
\hline P1 x P3 & 26.89 & 1.05 & 25.83 & 1.51 & 38.15 & 1.61 & $0.7: 1 \mathrm{c}$ \\
\hline P1 x P4 & 27.19 & 1.24 & 18.87 & 1.79 & 44.99 & 1.90 & $0.4: 1 \mathrm{a}$ \\
\hline P1 x P5 & 21.72 & 1.30 & 12.79 & 1.87 & 56.58 & 1.99 & $0.2: 1 \mathrm{a}$ \\
\hline P1 x P6 & 21.47 & 1.05 & 14.57 & 1.51 & 54.99 & 1.61 & $0.3: 1 \mathrm{a}$ \\
\hline $\mathrm{P} 2 \times \mathrm{P} 1$ & 21.43 & 1.02 & 14.39 & 1.47 & 54.82 & 1.56 & $0.3: 1 \mathrm{a}$ \\
\hline $\mathrm{P} 2 \times \mathrm{P} 3$ & 23.22 & 1.13 & 29.24 & 1.62 & 38.48 & 1.72 & $0.8: 1 \mathrm{c}$ \\
\hline $\mathrm{P} 2 \mathrm{x}$ P4 & 20.18 & 1.19 & 29.81 & 1.71 & 41.06 & 1.82 & $0.7: 1 \mathrm{c}$ \\
\hline $\mathrm{P} 2 \times \mathrm{P} 5$ & 20.79 & 1.27 & 16.58 & 1.82 & 54.15 & 1.94 & $0.3: 1 \mathrm{a}$ \\
\hline P2 x P6 & 22.32 & 0.93 & 18.33 & 1.34 & 50.67 & 1.42 & $0.4: 1 \mathrm{a}$ \\
\hline P3 x P1 & 19.69 & 1.01 & 38.68 & 1.45 & 32.17 & 1.54 & $1.2: 1 \mathrm{c}$ \\
\hline P3 x P2 & 25.02 & 1.13 & 35.61 & 1.62 & 30.46 & 1.72 & $1.2: 1 \mathrm{c}$ \\
\hline P3 x P4 & 23.19 & 1.30 & 65.24 & 1.87 & 2.50 & 1.99 & $26.1: 1 \mathrm{~b}$ \\
\hline P3 x P5 & 24.97 & 1.11 & 35.09 & 1.59 & 31.21 & 1.69 & $1.1: 1 \mathrm{c}$ \\
\hline P3 x P6 & 19.74 & 1.19 & 43.91 & 1.71 & 27.09 & 1.82 & $1.6: 1 \mathrm{~d}$ \\
\hline P4 x P1 & 23.23 & 1.07 & 30.99 & 1.54 & 36.44 & 1.63 & $0.9: 1 \mathrm{c}$ \\
\hline $\mathrm{P} 4 \times \mathrm{P} 2$ & 17.10 & 1.05 & 48.95 & 1.51 & 24.52 & 1.61 & $2.0: 1 \mathrm{~d}$ \\
\hline P4 x P3 & 21.69 & 1.41 & 66.57 & 2.02 & 2.57 & 2.15 & $25.6: 1 \mathrm{~b}$ \\
\hline P4 x P5 & 28.51 & 1.11 & 30.91 & 1.59 & 31.33 & 1.69 & $1.0: 1 \mathrm{c}$ \\
\hline P4 x P6 & 24.26 & 0.99 & 31.08 & 1.43 & 35.28 & 1.52 & $0.9: 1 \mathrm{c}$ \\
\hline P5 x P1 & 20.08 & 1.49 & 14.30 & 2.14 & 56.51 & 2.28 & $0.3: 1 \mathrm{a}$ \\
\hline P5 x P2 & 20.25 & 1.30 & 18.48 & 1.87 & 52.67 & 1.99 & $0.4: 1 \mathrm{a}$ \\
\hline P5 x P3 & 21.93 & 1.49 & 22.73 & 2.14 & 46.75 & 2.28 & $0.5: 1 \mathrm{a}$ \\
\hline P5 x P4 & 20.04 & 1.27 & 30.32 & 1.83 & 40.18 & 1.94 & $0.8: 1 \mathrm{c}$ \\
\hline P5 x P6 & 26.01 & 1.33 & 16.87 & 1.92 & 48.30 & 2.03 & $0.3: 1 \mathrm{a}$ \\
\hline P6 x P1 & 22.47 & 1.27 & 16.55 & 1.83 & 51.56 & 1.94 & $0.3: 1 \mathrm{a}$ \\
\hline P6 x P2 & 21.64 & 1.22 & 15.21 & 1.75 & 53.56 & 1.86 & $0.3: 1 \mathrm{a}$ \\
\hline P6 x P3 & 21.09 & 1.09 & 34.65 & 1.56 & 34.67 & 1.66 & $1.0: 1 \mathrm{c}$ \\
\hline P6 x P4 & 20.63 & 1.54 & 31.08 & 2.21 & 38.79 & 2.35 & $0.8: 1 \mathrm{c}$ \\
\hline P6 x P5 & 21.54 & 1.33 & 16.54 & 1.92 & 52.21 & 2.03 & $0.3: 1 \mathrm{a}$ \\
\hline LSD $(0.01 \%)$ & $4.95 * *$ & & $72.38 * *$ & & $61.54 * *$ & & \\
\hline
\end{tabular}

Symbols of groups (ratio C18:2/C18:3): a) (0.2-0.6):1; b) (25.0-34.0):1; c) (0.7-1.2:1); d) (1.3-2.0):1

Standard deviation (SD); Significant $F$ statistic: **at a level of $\alpha \leq 0.01$ 
Table 4 Effects of GCA for fatty acid content in the seeds of parental varieties of F1generation during 2014 and 2016 growing season

Significant $F$ statistic: *at a level of $\alpha \leq 0.05$; **at a level of $\alpha \leq 0.01$

Table 5 Effects of SCA for fatty acid content in the seeds of hybrid cultivars of F1 generation during 2014 and 2016 growing season
Significant $F$ statistic: *at a level of $\alpha \leq 0.05$; **at a level of $\alpha \leq 0.01$

\begin{tabular}{|c|c|c|c|c|c|c|}
\hline \multirow[t]{2}{*}{ Genotypes } & \multicolumn{2}{|c|}{ Oleic acid C18:1 } & \multicolumn{2}{|c|}{ Linoleic acid C18:2 } & \multicolumn{2}{|c|}{$\alpha$-Linolenic acid C18:3 } \\
\hline & 2014 & 2016 & 2014 & 2016 & 2014 & 2016 \\
\hline Szafir (P1) & $0.56 * *$ & -0.13 & $-11.16^{* *}$ & $-9.52 * *$ & $10.62 * *$ & $9.56 * *$ \\
\hline Oliwin (P2) & $0.45^{*}$ & $-2.46 * *$ & $-7.50 * *$ & $-5.51 * *$ & $7.28 * *$ & $8.22 * *$ \\
\hline Linola KLA (P3) & $-1.54 * *$ & 0.69 & $16.80 * *$ & $15.38 * *$ & $-15.27 * *$ & $-16.04 * *$ \\
\hline Linola KLB (P4) & $-1.19 * *$ & 0.50 & $16.61 * *$ & $13.74 * *$ & $-15.64 * *$ & $-14.39 * *$ \\
\hline Escalina (P5) & $1.17 * *$ & $1.51 * *$ & $-8.30 * *$ & $-8.34 * *$ & $7.40 * *$ & $7.05 * *$ \\
\hline Modran (P6) & $0.55 * *$ & -0.10 & $-6.44 * *$ & $-5.75^{* *}$ & $5.62 * *$ & $5.60 * *$ \\
\hline
\end{tabular}

\begin{tabular}{|c|c|c|c|c|c|c|}
\hline \multirow[t]{2}{*}{ Hybrids } & \multicolumn{2}{|c|}{ Oleic acid C18:1 } & \multicolumn{2}{|c|}{ Linoleic acid C18:2 } & \multicolumn{2}{|c|}{$\alpha$-Linolenic acid C18:3 } \\
\hline & 2014 & 2016 & 2014 & 2016 & 2014 & 2016 \\
\hline P1 x P2 & $2.14 * *$ & 0.23 & 2.31 & 1.05 & $-4.27 *$ & -1.62 \\
\hline P1 x P3 & -0.57 & 0.95 & $-5.69 * *$ & -0.89 & $6.30 * *$ & -0.13 \\
\hline P1 x P4 & 0.51 & $5.12 * *$ & $-9.49 * *$ & $-7.28 * *$ & $9.20 * *$ & 2.41 \\
\hline P1 x P5 & $-1.67 * *$ & -1.36 & $3.75^{*}$ & 2.70 & -2.29 & -1.28 \\
\hline P1 x P6 & -0.22 & -0.09 & $3.88 *$ & 2.14 & $-3.60 *$ & -1.64 \\
\hline $\mathrm{P} 2 \times \mathrm{P} 1$ & $-1.72 * *$ & 0.04 & -0.16 & 0.47 & 1.72 & -0.61 \\
\hline $\mathrm{P} 2 \times \mathrm{P} 3$ & $0.80^{*}$ & $4.95 * *$ & $-7.02 * *$ & $-5.49 * *$ & $5.99 * *$ & 0.57 \\
\hline $\mathrm{P} 2 \times \mathrm{P} 4$ & -0.15 & $-2.94 * *$ & 0.95 & 2.37 & -0.87 & 0.49 \\
\hline P2 x P5 & 0.20 & $-2.37^{*}$ & 2.82 & $3.56^{*}$ & $-2.69 *$ & -1.21 \\
\hline $\mathrm{P} 2 \times \mathrm{P} 6$ & -0.17 & 1.59 & 0.14 & 0.37 & -0.12 & -1.77 \\
\hline $\mathrm{P} 3 \times \mathrm{P} 1$ & -0.20 & $-4.92 * *$ & 2.88 & $7.84 * *$ & $-2.66^{*}$ & $-3.16 * *$ \\
\hline P3 x P2 & $-1.74 * *$ & $2.37 * *$ & -0.08 & $5.00 * *$ & 2.11 & $-7.41 * *$ \\
\hline $\mathrm{P} 3 \times \mathrm{P} 4$ & -0.25 & $3.09 * *$ & $10.56^{* *}$ & 1.88 & $-10.23 * *$ & $-4.72 * *$ \\
\hline P3 x P5 & -0.33 & 0.67 & $6.98 * *$ & $6.47 * *$ & $-6.61 * *$ & $-7.23 * *$ \\
\hline P3 x P6 & 0.08 & -0.82 & $4.45^{*}$ & $4.78 * *$ & $-4.32 *$ & $-3.85 * *$ \\
\hline P4 x P1 & -0.51 & $-3.96 * *$ & $11.15^{* *}$ & $2.97 *$ & $-10.88^{* *}$ & 0.86 \\
\hline $\mathrm{P} 4 \times \mathrm{P} 2$ & -0.60 & $-2.22 *$ & $7.01 * *$ & $11.03 * *$ & $-6.50 * *$ & $-9.11 * *$ \\
\hline P4 x P3 & 0.18 & -0.65 & -0.38 & 0.63 & 0.04 & 0.04 \\
\hline P4 x P5 & 0.19 & $6.16^{* *}$ & 3.67 & -1.62 & $-4.62 *$ & $-3.88 * *$ \\
\hline P4 x P6 & -0.74 & 1.81 & -0.23 & 0.93 & 1.15 & -2.70 \\
\hline P5 x P1 & $-0.88^{*}$ & 0.30 & 0.74 & 0.69 & -0.25 & -0.79 \\
\hline P5 x P2 & $1.25^{* *}$ & -1.43 & -0.39 & 1.81 & -0.93 & -0.38 \\
\hline P5 x P3 & $-0.91 *$ & $2.12 *$ & $-6.39 * *$ & $-8.67 * *$ & $7.51 * *$ & $6.82 * *$ \\
\hline $\mathrm{P} 5 \times \mathrm{P} 4$ & -0.40 & 1.51 & $-5.47 * *$ & $-3.95 * *$ & $5.51 * *$ & 2.20 \\
\hline P5 x P6 & -0.39 & $2.27 *$ & 1.73 & 2.62 & -1.62 & $-4.86^{* *}$ \\
\hline P6 x P1 & -0.60 & 1.78 & 1.76 & 0.46 & -1.23 & -2.57 \\
\hline P6 x P2 & 0.18 & -0.01 & -2.51 & -0.86 & 1.83 & 0.43 \\
\hline P6 x P3 & -0.22 & $-2.61 * *$ & -1.02 & 1.52 & 1.41 & 0.98 \\
\hline P6 x P4 & -0.19 & 0.60 & $-6.56^{* *}$ & $-6.94 * *$ & $6.88 * *$ & $6.55^{* *}$ \\
\hline P6 x P5 & $1.66^{* *}$ & $-6.14 * *$ & -0.65 & 0.32 & -1.29 & $5.20 * *$ \\
\hline
\end{tabular}


Genetic parameter estimation

Thus far, only a few studies have been conducted concerning the mode in which oleic, linoleic, and $\alpha$ linolenic acid are inherited in flax. Their inheritance is a complex trait which is determined by numerous genes. The inheritance of fatty acids has been better explained by the studies of Green (1986) and Rowland (1991) on low $\alpha$-linolenic acid flax mutants. Subsequently, two independent fatty acid desaturase genes with additive gene action were identified.

The analysis of variance conducted as described by Hayman (1954) showed that the additive effect of genes was significant for the content of linoleic and $\alpha$ linolenic acid. It was further observed that the significantly highest dominance of genes occurred for linoleic and $\alpha$-linolenic acid. Among the F1 hybrids, a significant asymmetry was noted in the distribution of alleles of genes determining the content of oleic, linoleic, and $\alpha$-linolenic acid (Table 6).

The significant role played by the additive effect of genes in determining 18-carbon fatty acids was also shown for rapeseed (Krzymański and Downey 1969; Hu et al. 2006; Coonrodet al. 2008; Mei et al. 2011; Yang et al. 2012; Spasibionek 2013). Jedyński (2003) showed that the additive effect of genes may significantly contribute to a rapid genetic progress; however, the considerable contribution of gene dominance may reduce the selection efficiency during the breeding process.

Assessment of genetic parameters was carried out for the contents of fatty acids as described by Mather and Jinks (1982) under both seasons $(2014,2016)$ (Table 7). For the content of linoleic and $\alpha$-linolenic acid, it was found that additive parameters (D) were considerably higher than the nonadditive ones $\left(\mathrm{H}_{1}, \mathrm{H}_{2}\right.$, and $\mathrm{h}^{2}$ ). This points to the dominance of additive action of genes in determining the content of linoleic and $\alpha$-linolenic acid. Assessment of mean dominance degree $\left(\mathrm{H}_{1} / \mathrm{D}\right)^{1 / 2}$ for oleic acid showed a value higher than unity $(1.07,2.87)$, meaning that complete dominance occurred in determining this acid. These values were lower than the ones for linoleic $(0.40,0.42)$ and $\alpha$-linolenic acid $(0.44,0.27)$, meaning that incomplete dominance occurred in determining the content of these acids. The estimated number of gene groups $\left(\mathrm{h}^{2} /\right.$ $\mathrm{H}_{2}$ ) that control the accumulation of fatty acids in the seed oil of the investigated F1 hybrids enabled determining one gene group for oleic, linoleic and $\alpha$ linolenic acid. However, a study on rapeseed showed that the content of oleic acid was determined by two groups of genes acting nonadditively, and that of linoleic and $\alpha$-linolenic acid by one group of additive genes (Spasibionek 2013).

The product of allele frequency in all loci $\left(\mathrm{H}_{2} /\right.$ $4 \times \mathrm{H}_{1}$ ) for analyzed acids was close to 0.25 , which indicated that almost equal frequency of dominant and recessive alleles occurred for oleic acid $(0.19,0.21)$, linoleic acid $(0.24,0.19)$, and $\alpha$-linolenic acid $(0.23$, $0.20)$. The ratio of dominant to recessive alleles $\left(\left[(\mathrm{DH} 1)^{1 / 2}+\mathrm{F}\right] /\left[(4 \mathrm{DH} 1)^{1 / 2}-\mathrm{F}\right)\right.$ was considerably greater than one, amounting to $(2.55,1.49)$ for oleic acid, $(1.73,2.90)$ for linoleic acid, and $(1.83,2.70)$ for $\alpha$-linolenic acid. This revealed the prevalence of dominant over recessive genes in determining the content of these acids.

In the present study, the heritability coefficients in the broad sense $\left(\mathrm{h}^{2} \mathrm{BS}\right)$ and in the narrow sense $\left(\mathrm{h}^{2} \mathrm{NS}\right)$ were similar and very high for linoleic $\left(\mathrm{h}^{2} \mathrm{BS}-0.88\right.$, $\left.0.89 ; \mathrm{h}^{2} \mathrm{NS}-0.97,0.98\right)$ and $\alpha$-linolenic acid $\left(\mathrm{h}^{2} \mathrm{BS}-\right.$

Table 6 Analysis of variance for the fatty acid content of hybrids of F1generation-according to Hayman

\begin{tabular}{|c|c|c|c|c|c|c|c|}
\hline \multirow[t]{3}{*}{ Source of variation } & \multirow[t]{3}{*}{ Degrees of freedom } & \multirow{2}{*}{\multicolumn{2}{|c|}{$\frac{\text { Oleic acid C18:1 }}{\text { Mean square }}$}} & \multicolumn{2}{|c|}{ Linoleic acid C18:2 } & \multicolumn{2}{|c|}{$\alpha$-Linolenic acid C18:3 } \\
\hline & & & & & & & \\
\hline & & 2014 & 2016 & 2014 & 2016 & 2014 & 2016 \\
\hline 1/Dominance & 15 & $12.73 * *$ & $23.90 * *$ & $74.95 * *$ & $59.11 * *$ & $80.55 * *$ & $26.64 * *$ \\
\hline 1a/Unidirection & 1 & 1.76 & $136.67 * *$ & $191.94 * *$ & $181.56^{* *}$ & $234.06 * *$ & 6.22 \\
\hline 1b/Asymmetry & 5 & $5.84 *$ & $13.96^{*}$ & 22.64 & $60.61 * *$ & $35.28 * *$ & $22.89 * *$ \\
\hline 2/Additivity & 5 & 4.35 & 11.81 & $2037.66 * *$ & $1558.40 * *$ & $1750.94 * *$ & $1690.57 * *$ \\
\hline
\end{tabular}

Significant $F$ statistic: *at a level of $\alpha \leq 0.05$; **at a level of $\alpha \leq 0.01$ 
Table 7 Estimates of genetic parameters for fatty acids of F1 seed hybrids during 2014 and 2016 growing season — according to Mather and Jinks

\begin{tabular}{|c|c|c|c|c|c|c|}
\hline \multirow[t]{2}{*}{ Parameter } & \multicolumn{2}{|c|}{ Oleic acid C18:1 } & \multicolumn{2}{|c|}{ Linoleic acid C18:2 } & \multicolumn{2}{|c|}{$\alpha$-Linolenic acid C18:3 } \\
\hline & 2014 & 2016 & 2014 & 2016 & 2014 & 2016 \\
\hline $\mathrm{D}$ & 6.15 & 6.05 & 851.09 & 811.01 & 766.40 & 729.26 \\
\hline $\mathrm{F}$ & 6.92 & 6.82 & 180.30 & 328.89 & 199.28 & 177.96 \\
\hline $\mathrm{H}_{1}$ & 7.73 & 49.89 & 133.30 & 139.99 & 151.37 & 51.22 \\
\hline $\mathrm{H}_{2}$ & 7.37 & 42.72 & 128.66 & 105.11 & 138.81 & 41.10 \\
\hline$h^{2}$ & 9.98 & 75.93 & 106.63 & 100.31 & 130.03 & 3.45 \\
\hline$\left(\mathrm{H}_{1} / \mathrm{D}\right)^{1 / 2}$ & 1.07 & 2.87 & 0.40 & 0.42 & 0.44 & 0.27 \\
\hline $\mathrm{h}^{2} / \mathrm{H}_{2}$ & 1 & 1 & 1 & 1 & 1 & 1 \\
\hline $\mathrm{H}_{2} / 4 \times \mathrm{H}_{1}$ & 0.19 & 0.21 & 0.24 & 0.19 & 0.23 & 0.20 \\
\hline$\left(\left[(\mathrm{DH} 1)^{1 / 2}+\mathrm{F}\right] /\left[(4 \mathrm{DH} 1)^{1 / 2}-\mathrm{F}\right.\right.$ & 2.55 & 1.49 & 1.73 & 2.90 & 1.83 & 2.70 \\
\hline $\mathrm{h}^{2} \mathrm{BS}$ & 0.58 & 0.19 & 0.88 & 0.89 & 0.86 & 0.94 \\
\hline$h^{2} \mathrm{NS}$ & 0.65 & 0.62 & 0.97 & 0.98 & 0.97 & 0.98 \\
\hline
\end{tabular}

$\left.0.86,0.94 ; \mathrm{h}^{2} \mathrm{NS}-0.97,0.98\right)$, which confirms the additive effect of genes in the inheritance of these acids. On the other hand, the lowest values were obtained for oleic acid $\left(\mathrm{h}^{2} \mathrm{BS}-0.58,0.19 ; \mathrm{h}^{2} \mathrm{NS}-0.65\right.$, 0.62 ), which confirms the nonadditive effect of genes for this trait (Table 7).

High values of $h^{2} B S$ indicate that most of the phenotypic variations observed for these traits are genetic in nature and the possibility of genetic gains is increased. You et al. (2016) found high heritability $\left(\mathrm{h}^{2} \mathrm{BS}\right)(>0.90)$ for linoleic and linolenic acid, whereas a moderate heritability for fat content (0.50-0.70). These results are consistent with those of Pleines and Friedt (1988), Khan et al. (2008), and Spasibionek (2013), who observed high $\mathrm{h}^{2} \mathrm{BS}$ when controlling these same traits in Brassica. Many authors believe that the higher the value of broadsense heritability is, the lower the environmental influence on the expression of the trait, given that this influence hinders the efficient selection of genotypes (Patel and Chopde 1981; Bhateria et al. 2006; Spasibionek 2013).

\section{Conclusions}

In the present study, important parental genotypes such as Linola KLA (P3) and Linola KLB (P4) were identified that could be utilized in crossing program to achieve the maximum variability toward changes in the proportion of fatty acids, mainly linoleic and $\alpha$ linolenic acid.

Significant GCA and SCA effects observed for the studied fatty acids imply that both additive (for linoleic and $\alpha$-linolenic acid) and nonadditive (for oleic acid) components of gene actions are involved in the inheritance. The prevalence of additive gene action in various characteristics indicates that using appropriate methods, such as diallel selective mating or cyclic selection, genetic improvement can be achieved through accumulating favorable alleles from parents with high GCA in the target genotype.

On the basis of the SCA effects, five cross combinations $(\mathrm{P} 3 \times \mathrm{P} 1, \quad \mathrm{P} 3 \times \mathrm{P} 4, \quad \mathrm{P} 3 \times \mathrm{P} 5$, $\mathrm{P} 3 \times \mathrm{P} 6, \mathrm{P} 4 \times \mathrm{P} 2$ ) were found to be promising F1 hybrids for use as a source population for further selection, to achieve fatty acid changes in linseed. These combinations allow selecting varieties with 1:1 and 2:1 ratio of omega-6:omega-3 fatty acids. Such a fatty acid composition in linseed is very beneficial for human health, as well as the oil has a longer shelf life.

Acknowledgements We are grateful to Krystyna Krótka MSc and Stanisław Spasibionek Ph.D her joint work on the manuscript. They also thank all the technical and laboratory staff Department of Genetics and Breeding of Oilseed Crops, Plant Breeding and Acclimatization Institute-National Research Institute (PBAI-NRI), Poznan, Poland for their technical assistance in conducting the experiments. 
Author contributions The first two authors contributed equally to this work, and should be regarded as joint First Authors. Walkowiak and Spasibionek conceived and designed the project, carried out the field experiments, collected data, and wrote the manuscript. Krótka performed the statistical analyses, and revised the manuscript. All authors read and approved the final manuscript.

\section{Funding None.}

Data availability Department of Genetics and Breeding of Oilseed Crops, Plant Breeding and Acclimatization InstituteNational Research Institute (PBAI-NRI), Strzeszyńska 36, 60-479, Poznan, Poland.

\section{Declarations}

Conflict of interest The authors declared that they no conflict of interest.

Open Access This article is licensed under a Creative Commons Attribution 4.0 International License, which permits use, sharing, adaptation, distribution and reproduction in any medium or format, as long as you give appropriate credit to the original author(s) and the source, provide a link to the Creative Commons licence, and indicate if changes were made. The images or other third party material in this article are included in the article's Creative Commons licence, unless indicated otherwise in a credit line to the material. If material is not included in the article's Creative Commons licence and your intended use is not permitted by statutory regulation or exceeds the permitted use, you will need to obtain permission directly from the copyright holder. To view a copy of this licence, visit http://creativecommons.org/licenses/by/4.0/.

\section{References}

Ahmed M, Pickova J, Ahmad T, Liaquat M, Farid A, Jahangir M (2016) Oxidation of lipids in foods. Sarhad J Agric 32(3):230-238. https://doi.org/10.17582/journal.sja/2016. 32.3.230.238

Baker RJ (1978) Issues in diallel analysis. Crop Sci 18:533-536

Bhateria S, Sood SP, Pathania A (2006) Genetic analysis of quantitative traits across environments in flax (Linum usitatissimum L.). Euphytica 150:185-194. https://doi.org/10. 1007/s10681-006-9106-7

Bickert C, Lühs W, Friedt W (1994) Variation for fatty acid content and triacylglycerol composition in different Linum species. Ind Crops Prod 2:229-237. https://doi.org/10. 1016/0926-6690(94)90040-X

Caliński T, Czajka S, Kaczmarek Z, Krajewski P, Siatkowski I (1998) SERGEN Statistical methodology and usage of the program SERGEN (Version 3 for Windows 95) analysis of series of plant genetic and breeding experiments. IGR PAN, Poznań, 1-42

Choe E, Min DB (2009) Mechanisms of antioxidants in the oxidation of foods. Compr Rev Food Sci Food Safety
8:345-358. https://doi.org/10.1111/j.1541-4337.2009. 00085.x

Christie BR, Shattuck VI (1992) The diallel cross: design analysis and use for plant breeders. Plant Breed Rev 9:9-36. https://doi.org/10.1002/9780470650363.ch2

Coonrod D, Brick MA, Byrne PF, DeBonte L, Chen Z (2008) Inheritance of long chain fatty acid content in rapeseed (Brassica napus L.). Euphytica 164:583-592

Coskuner Y, Karababa E (2007) Some physical properties of flaxseed (Linum usitatissimum L.). J Food Eng 78:1067-1073. https://doi.org/10.1016/j.jfoodeng.2005. 12.017

Dribnenki JCP, Green AG (1995) LinolaTM ‘947’ low linolenic acid flax. Can. J. Plant Sci. 75(1):201-202. https://doi.org/ 10.4141/cjps95-036

Dribnenki JCP, McEachern SF, Green AG, Kenaschuk EO, Rashid KY (1999) LinolaTM '1084' low-linolenic acid flax. Can J Plant Sci 79(4):607-609. https://doi.org/10. 4141/P99-053

Dribnenki JCP, McEachern SF, Chen Y, Green AG, Rashid KY (2003) LinolaTM 2047 low linolenic flax. Can J Plant Sci 83(1):81-83. https://doi.org/10.4141/P02-040

Dribnenki JCP, McEachern SF, Chen Y, Green AG, Rashid KY (2004) 2090 low linolenic acid flax. Can J Plant Sci 84(3):797-799. https://doi.org/10.4141/P03-183

Dribnenki JCP, McEachern SF, Chen Y, Green AG, Rashid KY (2005) 2126 low linolenic flax. Can J Plant Sci 85(1):155-157. https://doi.org/10.4141/P04-051

Dribnenki JCP, McEachern SF, Chen Y, Green AG, Rashid KY (2007) 2149 Solin (low linolenic flax). Can J Plant Sci 87(2):297-299. https://doi.org/10.4141/P05-082

Drozdowski B (2007) Lipidy. W: Chemia żywności. Sacharydy, lipidy i białka. Eds. Sikorski Z., WNT, Warszawa. (in Polish)

Falconer DS (1975) Introduction to quantitative genetics. Donald Press Co., New York, NY

FAOSTAT (2018) http://www.fao.org/faostat/en/

Galano JM, Lee YY, Durand TJ, Lee JCY (2015) Special Issue on Analytical Methods for Oxidized Biomolecules and Antioxidants The use of isoprostanoids as biomarkers of oxidative damage and their role in human dietary intervention studies. Free Radical Research, Early Online: 1-16. https://doi:https://doi.org/10.3109/10715762.2015. 1007969

Góral H, Ejsmont M (2008) Analiza zdolności kombinacyjnych i odziedziczalność cech plonotwórczych lnu oleistego (Linum usitatissimum L.). Biuletyn IHAR 249:209-215 (in Polish)

Góral H, Jasieński M, Zając T (2006) Zdolność kombinacyjna odmian lnu oleistego pod względem cech plonotwórczych. Biuletyn IHAR 240(241):237-242 (in Polish)

Green AG (1986) A mutant genotype of flax (Linum usitatissimum L.) containing very low levels of linolenic acid in its seed oil. Can J Plant Sci 66(3):499-503. https://doi.org/10. 4141/cjps86-068

Green AG, Marshall DR (1984) Isolation of induced mutants in linseed (Linum usitatissimum) having reduced linolenic acid content. Euphytica 33(2):321-328. https://doi.org/10. 1007/BF00021128

Green AG, Chen Y, Singh SP, Dribnenki JCP (2008) Flax. In: Kole C, Hall TC (eds) Compendium of transgenic crop 
plants: transgenic oilseed crops. Blackwell Publishing Ltd, Oxford, pp 199-226

Griffing B (1956) Concept of general and specific combining ability in relation to diallel crossing system. Aust J Biol Sci 9:463-493

Hall LM, Booker H, Siloto RMP, Jhala AJ, Weselake RJ (2016) Flax (Linum usitatissimum L.). In: McKeon TA, Hayes D, Hildebrand D, Weselake RJ (eds) Industrial oilseed crops. AOCS Oilseed Monograph series, pp 157-194

Hallauer RA, Carena MJ, Miranda JB (2010) Handbook of plant breeding. Quantitative genetics in maize breeding, 1st edn. Springer, New York, NY

Hayman BJ (1954) The theory and analysis of diallel crossed. Genetics 39:789-809

Heller K, Andruszewska A, Wielgusz K (2010) The cultivation of linseed by ecological methods. J Res Appl Agri Eng 3:112-116

Hu X, Sullivan-Gilbert M, Gupta M, Thompson SA (2006) Mapping of the loci controlling oleic and linolenic acid contents and development of fad 2 and fad 3 allele-specific markers in canola (Brassica napus L.). Theor Appl Genet 113:497-507. https://doi.org/10.1007/s00122-006-0315-1

Jedyński S (2003) Analiza dialleliczna cech ilościowych mieszańców $F_{1}$ pszenicy jarej. Biuletyn IHAR 226(227):127-134 (in Polish)

Kala R, Dobek A, Chudzik H, Kiełczewska H (1996) System analiz statystycznych doświadczeń genetyczno-hodowlanych, wersja 2.0. Katedra Metod Matematycznych i Statystycznych, Akademia Rolnicza Poznań. Podręcznik użytkownika User manual. (in Polish)

Keller J, Camaré C, Bernis C, Astello-García M, Barba de la Rosa AP, Rossignol M, del Socorro Santos Díaz M, Salvayre R, Negre-Salvayre A, Françoise G (2015) Antiatherogenic and antitumoral properties of Opuntia cladodes: inhibition of low density lipoprotein oxidation by vascular cells, and protection against the cytotoxicity of lipid oxidation product 4-hydroxynonenal in a colorectal cancer cellular model. J Physiol Biochem 71(3):557-587. https://doi.org/10.1007/s13105-015-0408-X

Khan S, Farhatullah KIH, Khan MY, Ali N (2008) Genetic variability, heritability and correlation for some quality traits in F3:4 Brassica napus populations. Sarhad J Agric 24(2):223-231

Krzymański J, Downey KR (1969) Inheritance of fatty acid composition in winter forms of rapseed (Brassica napus). Can J Plant Sci 49:313-319

Krzymański J, Piętka T, Krótka K (1993) Zdolność kombinacyjna i heterozja mieszańców diallelicznych rzepaku ozimego podwójnie ulepszonego I. pokolenie $F_{1}$. Postępy Nauk Rolniczych 5/245:41-52. (in Polish)

Kumar S, Singh JK, Vishwakarma A (2018) Importance of Linseed Crops in Agricultural Sustainability. Int J CurrMicrobiol App Sci 7(12):1198-1207. https://doi.org/ 10.20546/ijcmas.2018.712.149

Machikowa T, Saetang Ch, Funpeng K (2011) General and specific combining ability for quantitative characters in sunflower. J Agric Sci 3(1):91-95. https://doi.org/10.5539/ jas.v3n1p91

Mather K (1949) Biometrical genetics: the study of continuous variation. Methuen and Co, London UK
Mather K, Jinks JL (1982) Biometrical genetics: the study of continuous variation, 3rd edn. Chapman Hall, London UK

Mei G, Xun L, Chunyun G. (2011) Inheritance law of oleic acid character on Brassica napus. $13^{\text {th }}$ inter. Rapeseed Congres, Prague, Czech Republic, CD 745-748

Mercel LC, Wynne JC, Young CT (1990) Inheritance of fatty acid content in peanut oil. Peanut Sci 17(1):17-21. https:// doi.org/10.3146/i0095-3679-17-1-7

Morris DH (2007) Flax - A Health and Nutrition Primer. Fourth editio $1-140$

Mueller K, Eisner P, Yoshie-Stark Y, Nakada R, Kirchhoff E (2010) Functional properties and chemical composition of fractionated brown and yellow linseed meal (Linum usitatissimum L.). J Food Eng 98:453-460. https://doi.org/10. 1016/j.jfoodeng.2010.01.028

Patil VD, Chopde PR (1981) Combining ability analysis over environments in diallel crosse of linseed (Linum usitatissimum L.). Theor Appl Genet 60:339-343. https://doi.org/ 10.1007/bf00264325

Pimentel AJB, Souza MA, Carneiro PCS, Rocha JRASC, Machado JC, Ribeiro G (2013) Partial diallel analysis in advanced generations for selection of wheat segregating populations. Pesq Agropec Bras 48:1555-1561

Pleines S, Friedt W (1988) Breeding for improved C 18-fatty acid composition in rapeseed (Brassica napus L.). Fat Sci Technol 90:167-171. https://doi.org/10.1002/lipi. 19880900502

Rowland GG (1991) An EMS-induced low-linolenic-acid mutant in McGregor flax (Linum usitatissimum L.). Can J Plant Sci 71:393-396

Spasibionek S (2013) Genetic and breeding study of winter oilseed rape (Brassica napus L.) mutants with changed fatty acid composition. In: PBAI-NRI, editor. Monographs and Scientific Dissertations: 47. (in Polish)

Sughroue JR (1995) Proper analysis of the diallel mating design. Retrosp Theses Diss 10987:1-102

Teodoro LPR, Bhering LL, Gomes BEL, Campos CNS, Baio FHR, Gava R, de Silva Junior SA, Teodor PE (2019) Understanding the combining ability for physiological traits in soybean. PLoS ONE 14(12):e0226523. https://doi. org/10.1371/journal.pone.0226523

Wielebski F, Wójtowicz M, Spasibionek S (2016) Wpływ nawożenia azotem i siarką na plonowanie żółto i brązowonasiennych odmian lnu oleistego (Linum usitatissimum L.). Fragm Agron 33(4):134-144 (in Polish)

Yang Q, Fan C, Guo Z, Qin J, Wu J, Li Q, Fu T, Zhou Y (2012) Identification of FAD2 and FAD3 genes in Brassica napus genome and development of allele-specific markers for high oleic and low linolenic acid contents. Theor Appl Genet (2012) 125:715-729. https://doi.org/10.1007/ s00122-012-1863-1

You FM, Jia G, Cloutier S, Booker HM, Duguid SD, Rashi KY (2016) A method of estimating broad-sense heritability for quantitative traits in the type 2 modified augmented design. J Plant Breed Crop Sci 8(11):257-272. https://doi.org/10. 5897/JPBCS2016.0614

Publisher's Note Springer Nature remains neutral with regard to jurisdictional claims in published maps and institutional affiliations. 